\title{
Study of the Drying Phenomenon in Pine Trees
}

\author{
Petru BURDUHOS ${ }^{1}$, Ioan OROIAN ${ }^{1 *}$, Ilie COVRIG ${ }^{2}$, Constantin ŞULEA ${ }^{1}$ \\ ${ }^{1}$ Faculty of Agriculture. University of Agricultural Science and Veterinary Medicine, \\ Cluj - Napoca, România \\ ${ }^{2}$ Faculty of Horticulture. University of Agricultural Science and Veterinary Medicine, \\ Cluj - Napoca, România \\ *corresponding author, e-mail: neluoroian@gmail.com
}

Bulletin UASVM series Agriculture 73(1) / 2016

Print ISSN 1843-5254, Electronic ISSN 1843-5394

DOI 10.15835/buasvmcn-agr: 12004

\begin{abstract}
The history of the pine forests in our country has not only a decorative action, but also important consequences on soil stability and air quality n large areas. As all other forest tree species pine is sensitive to climatic changes, of which appearance is more and more claimed all over the world. One of the most harmful effects of this reality may be represented, as direct consequence, by pine trees drying. Nominating the main causes responsible for degradation of pine forests as direct consequence of drying phenomena, and identification of possible implications of temperature increase in concerned area, as consequence of climatic changes. Two years trial was implemented in Mureş County, during 2013, in a pine forest. The raw data were processed with STATISTICA v. 7.0 Office. The importance of identification of complex factors affecting the drying in pine forests is reflected by the extension of this phenomenon. Further research is needed in order to identify the best practices for diminishes the harmful consequences of drying rhythm in pine tree forests.
\end{abstract}

Keywords: best practices, climatic changes, research

\section{INTRODUCTION}

The history of the pine forests in our country has not only a decorative action, but also important consequences on soil stability and air quality in large areas (Domec et al., 2009).

As all other forest tree species pine is sensitive to climatic changes, of which appearance is more and more claimed all over the world (Burduhos et al., 2013; Burduhos et al, 2015). One of the most harmful effects of this reality may be represented, as direct consequence, by pine trees drying (Timofte, 2007) .

Nominating the main causes responsible for degradation of pine forests as direct consequence of drying phenomena, and identification of possible implications of temperature increase in concerned area, as consequence of climatic changes.

\section{MATERIALS AND METHODS}

A two years trial was implemented in Mureş County, during 2012 - 2013, in a pine forest. Data concerning pine drying phenomena frequency and intensity were weekly collected. Meteorological conditions were obtained from regional stations.

Averages and dispersion parameters of pine loses due to drying phenomena were calculated. The raw data were processed with STATISTICA v. 7.0 Office.

\section{RESULTS AND DISCUSSION}

The study developed during 2012 and 2013 allowed us to identify the main drying causes in pine trees. About $40 \%$ are the consequence of pest and pathogens intensified attack degrees, that are strongly correlated with temperature increase as correlations between these agents and climatic conditions emphasize (they are stronger in 2013, a dry and warm year), compared to 2012 that was a less warm and dry year.

We also identified particularities in manifesting resistance against the complex phenomenon 
determining drying advantaging conditions function of soil and light regimen in concerned area.

The study of the dynamic process of pine tree drying phenomenon in the experimental field located in Forestry District Târgu Mureş, during 2012-2013 (Fig. 1), indicates a concerning evolution consistent with the date regarding the experimental field assembling and which continues the tendency recorded for the past 14 years (Tab. 1).

If we take into consideration all the 50 pine tree monitored samples inside the experimental filed 20 of U.I. I Sabed from the Forestry District Targu Mures, we can observe an increase of the degree of injury from $22 \%$ at the start of the experimental period in 2012 up to $28 \%$ in 2014, at the end of the experiment (Fig. 1). The percent of dryness has doubled from 2012 till 2014, rising from $5 \%$ to $10 \%$ (Fig. 1).

If we analyze the date offered by Forestry District Târgu Mureș, regarding the whole experimental field, it appears that the number of shafts that presents the drying phenomenon in the studied areal has increased since 2012 from 21\% to $25 \%$ in 2014 (Fig. 2).

The experimental forest area, characterized by pine presence, affected by dryness has increased by 1 ha in 2012, in comparison with 2014, from 6 to 7 ha (Fig. 2).

It notes that, over the total number of pines existing in the experimental field where there was a $4 \%$ increase in the percentage of unhealthy trees, our observations showed a higher percentage, $6 \%$, which can be explained by regional variations

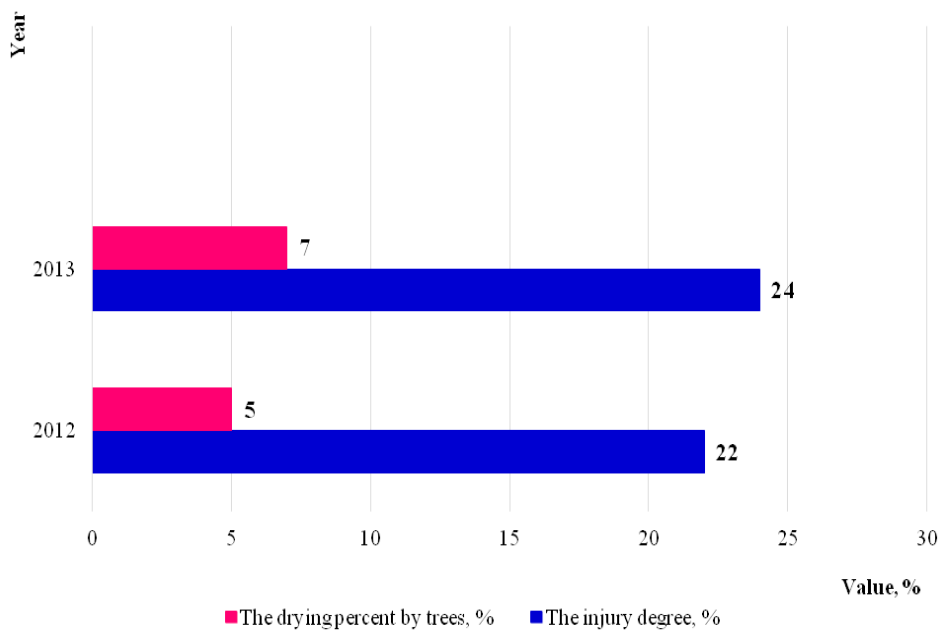

Fig. 1. The evolution of the injury degree and drying percent by trees within experimental field located in Târgu Mureș Forestry District, county of Mureș, 2012-2013

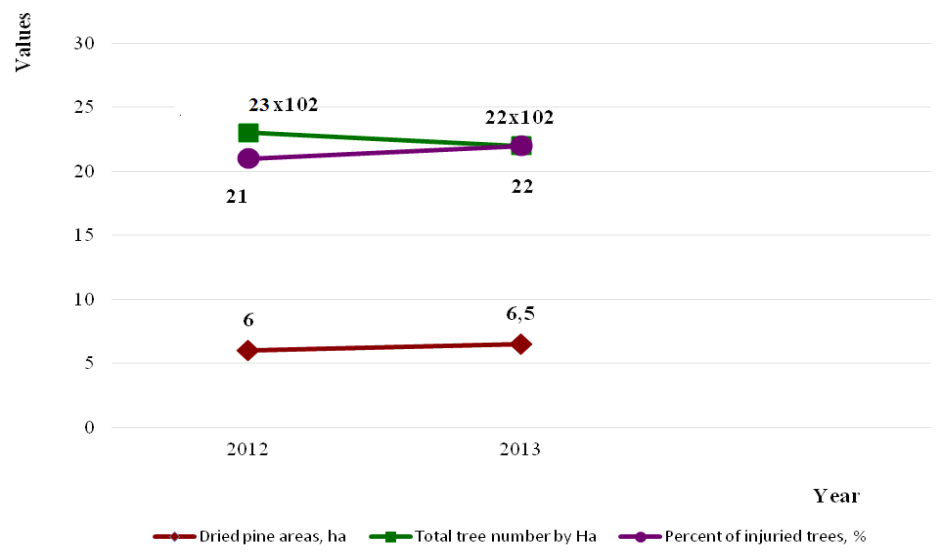

Fig. 2. The evolution of the drying phenomenon within experimental field located in Târgu Mureș Forestry District, county of Mureş during experimental period 2012-2013 
Tab.1. The evolution of the drying phenomenon within experimental field located in Târgu Mureş Forestry District, county of Mureş during 2010 - 2014

\begin{tabular}{cccccc}
\hline Issue $/$ Year & 2000 & 2010 & 2011 & 2012 & 2013 \\
\hline Dried pine areas & 4 & 5 & 6 & 6 & 6,50 \\
\hline Total tree number/ha & 2600 & 2500 & 2400 & 2300 & 2200 \\
\hline Percent of injured trees & 13 & 17 & 20 & 21 & 22 \\
\hline
\end{tabular}

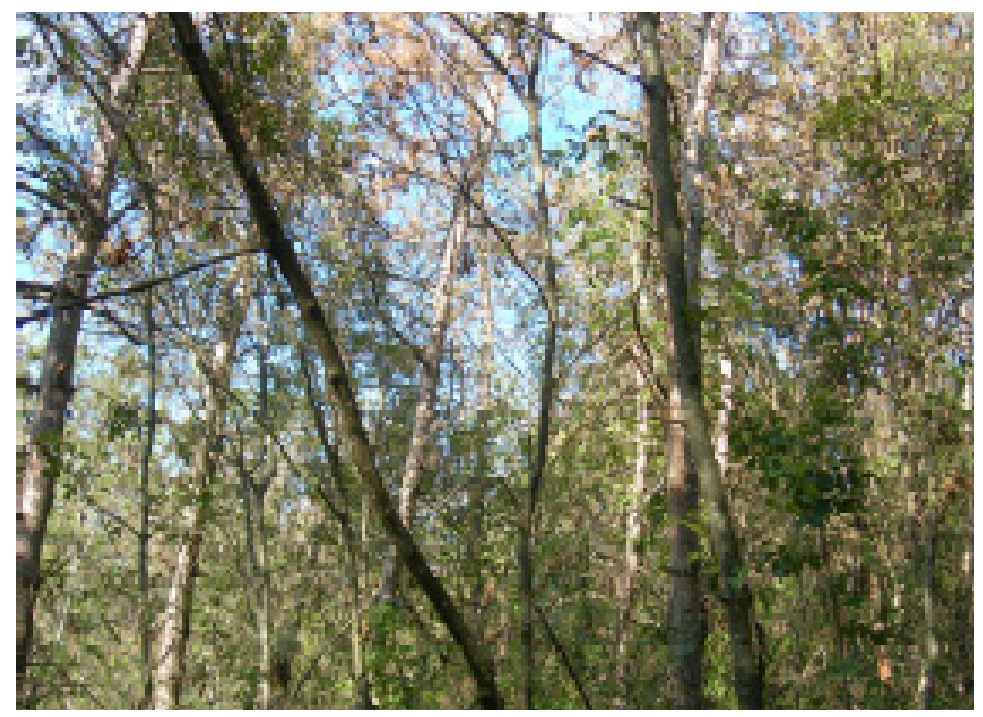

Fig. 3. Pine trees affected by weak to moderate drying (original)

in both the intensity and frequency of attacks pathogens and pests and weather conditions.

The report regarding the drying phenomenon recorded in the experimental field, in 2000, shows a concerning increased in the last four years. Thus, if in the year 2000 were reported 2600 trees/ha, in 2010 the number highlighted a decrease to 2500 , and after, a plummet characterized with a constant rhythm, illustrated by the annual number, which in 2011 where 2400 trees/ha, 2012 were 2300 trees/ha and in 2014 reached the lowest number 2100 trees/ha (Fig. 3). In percentage, the number of affected shafts increased from 2000 when it was $35 \%$, with $4 \%$ in 2010 . In the four year timeline 2010-2014, 2014 will record an increase of $5 \%$, reaching $25 \%$ superior to the 10 year timeline previously analyzed (table 1). Also, we can observe that the pine affected surfaces in the experimental areal have increased from 4 ha in 2000 to 5 ha in 2010, and in the year 2014 to reach 7 ha (table 1).

Noteworthy is the worrying percentage of pines, equal to $25 \%$ and according to our study is the upward trend, which belong to the category of unhealthy trees with low height (Fig. 3).

\section{CONCLUSION}

The importance of identification of complex factors affecting the drying in pine forests is reflected by the extension of this phenomenon. Further research is needed in order to identify the best practices for diminishes the harmful consequences of drying rhythm in pine tree forests.

\section{REFERENCES}

1. Burduhos P, Oroian I, Covrig I, Holonec L, Şulea C (2013). Identification of Debris Phenomena in Pine Trees, and Ways of their Management. Bulletin UASVM, Series Agriculture, 70(2): 321 - 324.

2. Burduhos P, Oroian I, Covrig I (2015). Emphasiying Interrelations between parasites in Pine Tree. ProEnvironment, 8(20): $80-84$.

3. Domec JC, Palmroth S, Ward E, Maier CA, Therezien M, Oren R (2009). Acclimation of leaf hydraulic conductance and stomatal conductance of Pinus taeda (loblolly pine) to long-term growth in elevated $\mathrm{CO}_{2}$ (free-air $\mathrm{CO}_{2}$ enrichment) and $\mathrm{N}$-fertilization. Plant Cell Environment (32): 1500-1512.

4. Timofte AI (2007). Explotarea pădurilor. Editura Universității din Oradea, Oradea. 